\title{
Effect of import decisions in Turkey on the red meat sector
}

\author{
Ahmet Cumhur AKIN ${ }^{1}$, Mehmet Saltuk ARIKAN²${ }^{2}$, Mustafa Bahadır ÇEVRIMLi' ${ }^{3}$
}

\begin{abstract}
${ }^{1}$ Mehmet Akif Ersoy University, Faculty of Veterinary Medicine, Department of Animal Health Economics and Management, 15030, Burdur/TURKEY
${ }^{2}$ Frrat University, Faculty of Veterinary Medicine, Department of Animal Health Economics and Management, 23119, Elazı̆̆/TURKEY

${ }^{3}$ Selçuk University, Faculty of Veterinary Medicine, Department of Animal Health Economics and Management, 42003, Konya/TURKEY
\end{abstract}

Key Words:

cattle fattening

livestock policies

import

red meat

Turkey

\author{
Anahtar Kelimeler: \\ sığır besiciliği \\ havvancılık politikaları \\ ithalat \\ kirmız1 et \\ Türkiye
}

Received: 22.04.2020

Accepted: 14.06.2020

Published Online: 29.08.2020

Article Code: 725022

Correspondence:

MS. ARIKAN

(msarikan@firat.edu.tr)

\section{ORCİD:}

AC. AKIN: 0000-0003-3732-0529

MS ARIKAN: 0000-0003-4862-1706

MB. ÇEVRIMLI: 0000-0001-5888-242X

\begin{abstract}
The products obtained as a result of animal production has an essential place within the food products from the point of the consumers. Increasing population and rising socio-economical welfare level in Turkey gradually increase demand for such products. Although all red meat in Turkey is met from cattle and small cattle, \% $\% 8$ of the existing demand is met from beef meat. Not being able to meet the demand to beef meat by production and the increases occurred at the prices has caused to point the red meat as one of the main actors in the public opinion. An effort is made to eliminate through import the insufficiency in supply of beef meat since 2010. Purpose of this study is to examine the reflections of the state interventions, policies and support applications on the red meat market to the sector and stockbreeders between 2010 and 2019, chronologically in the light of the debates in the public opinion. Although a total of 3.823.961 stockbreeding and butchery beef and 292.448 tons carcass and cut meat are imported to Turkey in the examined period, stability could not be provided in the market prices and the import-dependent applications has caused the stockbreeders to decrease their capacity or shut down. As a result, it is tried to provide a short term solution with red meat import decisions in red meat, but price stability cannot be provided.
\end{abstract}

\section{Türkiye'de ithalat kararlarının kırmızı et sektörüne etkisi}

\section{ÖZ}

Hayvansal üretim sonucu elde edilen ürünler, tüketiciler açısından gıda ürünleri içerisinde önemli bir yere sahiptir. Türkiye'de artan nüfus ve yükselen sosyo-ekonomik refah düzeyi bu ürünlere olan talebi her geçen gün artırmaktadır. Türkiye'de kırmızı etin tamamı büyükbaș ve küçükbaș hayvanlardan sağlanmakla birlikte mevcut talebin \%88'i sığır etinden karșılanmaktadır. Sı̆̆ır etine olan talebinin üretimle karşılanamaması ve fiyatlarda meydana gelen artışların kamuoyunda mevcut enflasyonun baş aktörlerinden biri olarak kırmızı etin gösterilmesine neden olmuştur. Sı̆̆ır etinde 2010 yılından günümüze kadar olan dönemde arzdaki yetersizlik ithalat yolu ile giderilmeye çalıșılmıștır. Bu çalıșmanın amacı; 20102019 yılları arasında alınan ithalat kararları, kırmı et piyasasına yapılan devlet müdahaleleri, politika ve destekleme uygulamalarının sektöre ve besicilere olan yansımalarının kamuoyundaki tartışmalar 1șığında kronolojik olarak irdelenmesidir. Türkiye'de incelenen dönemde toplam 3.823.961 baș besilik-kasaplık sığır ve 292.448 ton karkas ve parça et ithalatı yapılmasına rağmen piyasa fiyatlarında istikrar sağlanamadığ1 gibi ithalata dayalı uygulamalar, besicilerin kapasitelerini azaltmalarına veya üretimden çekilmelerine neden olmuştur. Sonuç olarak kırmızı ette alınan ithalat kararları ile kısa dönemde çözüm oluşturulmaya çalışılsa da fiyatlarda istikrar sağlanamamıştır.
This study is an extended version of the oral presentation presented at the 1 st International Health Science And Life Congress in Burdur on May $02-05,2018$.
The inability to meet the current demand for red meat in Turkey with domestic sources and the increases in prices caused the public to show red meat as the main actor of the current inflation. Turkey in the 2005-2013 period, retail beef prices increased by 130 per cent retail sheep meat prices have increased by 154 per cent. Increases in meat prices for the same period were higher than the rise in the CPI food index, which was $118 \%$ (3). At this point, to meet the current demand and reduce the supply gap in red meat, further import decisions have been taken. As a result of these decisions, the red meat market faced government interventions.

In recent years, the effectiveness of red meat imports in lowering the domestic market prices, the pressure of animal feed costs on red meat prices, and how the producer prices will 
follow in the coming period are discussed (4).

This study aims to examine the state interventions, policies and support practices in the red meat market between 2010 and 2019 in chronological order in light of the public debate.

\section{FACTORS FORMING THE BASIS FOR RED MEAT IMPORTS}

In 2008, raw milk prices in Turkey fell excessively, and approximately 1 million head of cattle were slaughtered, resulting in a decrease in the presence of cattle. The decline in the number of cows was reflected in red meat prices in 2009. In 2010, a decision was made to import livestock to reduce red meat prices. In this period, producers were encouraged to establish new businesses by giving interest-free loans. However, with the loans and supports given, cattle imports were made because the number of cattle in Turkey was insufficient.

\subsection{LIVESTOCK AND RED MEAT IMPORT DECISIONS AND EFFECTS HAVE TAKEN BETWEEN 2010-2019}

In 2010, the Ministry of Food, Agriculture, and Livestock decided to lower customs duties on the import of livestock and red meat to offset the real price increases in the red meat market (5).

With the decision of the council of ministers, the import authorization was first given to the Meat and Fish Institution. Afterwards, the customs tax was reduced for imports of the private firms operating in the sector with the Meat and Fish Institution. In the ongoing process, nine decisions regarding the import of live animals and red meat were issued by the council of ministers until 31 December 2010 (6).

In this period, the variability in the red meat market was also examined by the Competition Authority. In the report published by the competition institution, it was underlined that the involvement of the Meat and Fish Institution both in the red meat sector as an actor and a regulator inevitably causes a conflict of interest. As a result, the institution may be deprived of the ability to make independent and objective decisions expected from the regulatory authorities (7).

The price of the carcass meat brought through imports was below the carcass costs of domestic producers, causing the breeders to make a loss. In March 2011, the red meat import customs duty rate increased from $30 \%$ to $45 \%$, to $60 \%$ in May and to $75 \%$ in July, and domestic breeders were protected against economic damage $(8,9,10)$. With the decision of the Council of Ministers issued in December to continue importing red meat, Meat and Fish Institution's authority to import was extended until the end of 2012 (11). In 2012, $75 \%$ of customs duty applicable to carcass meat import was increased to $100 \%$ (12).

In the strategic plan prepared by the Ministry of Food, Agriculture, and Livestock in 2013, the emphasis was placed on increasing the amount of production in red meat with a supply gap, ensuring supply security and preventing price fluctuations. For this purpose, it is aimed to prevent price fluctuations and sustainable supply security in red meat by ensuring that the meat/feed parity remains in the $22-25$ range (13).

On the other hand, within the framework of general livestock policy, the name of the General Directorate of Meat and Fish Institution, which was established to ensure that it plays a regulatory and supportive role in the livestock sector, and to maintain its activities with public interest by contributing to the establishment of full competition conditions within the market economy rules, and General Directory of Meat and Milk Board, and the market was authorized to intervene (14).

Red meat imports were initiated in Turkey between 2007 and 2013, covering the ninth Development Plan period, during which direct payments were made to support domestic livestock production. Although the resources transferred to livestock enterprises have been significantly increased, it is observed that input costs in livestock enterprises are quite high and increase with each passing day when comparisons are made with various countries. For example, the cost of 1 $\mathrm{kg}$ of live weight in beef cattle was calculated as \$ 0.59 in Nigeria (15) and \$ 0.87 in the United States (16). However, this cost is estimated to be $\$ 3.40$ in Turkey (17). In addition to increased input costs; producer-collector-livestock-traderhandler-wholesaler-retailer and consumer in the marketing chain, the consumer price of many products the manufacturer is transferred to the next process from the decrease in the share of production shows that the production support (18).

To provide financial support to this country due to the flood disaster in Bosnia and Herzegovina on 13 May 2014, within the framework of the quota of the tariff, the General Directory of Meat and Milk Board was authorized to import 15 thousand tons of beef with zero customs in July (19). By the public; While discussing more than two months after the flood disaster in Bosnia and Herzegovina, the decision to import before a sacrifice feast and whether there will be imports for a long time, it was evaluated as an application to decrease the price of livestock and the carcass meat price sold by the producer (20).

Since there is no restriction on the decisions taken in the import of red meat, the person who wants can import. However, with a decision taken in September 2014, it was stipulated to be fattening to import. In this context, $40 \%$ of the current domestic beef cattle assets are allowed to import cattle. Although the customs tax to be applied to imports is determined as $15 \%$, it is decided that the live weight of the animal should be a maximum of $300 \mathrm{~kg}$ and not more than one year old (21).

In this period, the mobility in the red meat market and fluctuations in meat prices attracted the attention of nongovernmental organizations. It was emphasized that when the state intervention (regulations) is required, the cause-effect relationship between market failure and intervention should 
be established healthily and that the interventions may lead to market disruptions that are not compensated in the long term, and that decisions should be taken away from short-term political concerns (22). In another report, it was emphasized that the price instability in the meat market negatively affects breeders, public, and industrialists, and the General Directory of Meat and Milk Board cannot respond to the needs of the sector in eliminating these negativities (23).

In 2015, import practices to meet domestic demand continued. In the Central Bank's July 2015 report, it was emphasized that the upward trend in red meat prices continued and this increase negatively affected food and catering prices (24). With the decisions taken following this report, the customs tax rate applied on imports was first reduced to 0 , and then 30,000 tons of fresh or chilled beef meat was issued through the General Directory of Meat and Milk Board $(25,26)$. With these decisions, while the importation of live fattening animals continued, on the other hand, carcass meat imports were allowed, and meat prices were tried to be reduced before a feast of sacrifice.

Turkey's developments in red meat production "alarming" describing the Food Agriculture and Livestock Ministry, stressed that red meat is in demand with each passing day increases the other hand, red meat demands of the busiest in the summer increased the sacrificial slaughter of animals because of the Feast of Sacrifice (27).

It is stated at every opportunity that the main reason for the increase in red meat prices is due to the high input costs of the producers. The most important share in these inputs is feed. While the increase in the dollar rate directly affects the prices of these products, external dependence on feed raw materials also makes price control difficult.

In the first week of 2016, the Value Added Tax (VAT) rate on raw materials used in feeds and the production of these feeds have been reduced from $8 \%$ to $1 \%$ to reduce the costs of the producers (28). Following the decision taken, feed price hikes prevented the tax cuts, and the feed prices became cheaper, as well as the producers, making the feed more expensive than before (29).

Two official institutions have been authorized for the importation of live animals by the decision of the Council of Ministers published in the 3 May 2016 issue of the Official Gazette. According to the decision taken, the General Directory of Meat and Milk Board was granted 400 thousand heads of beef import authorization, and the General Directorate of Agricultural Enterprises, 150 thousand head breeder heifers were authorized. With this decision, it was authorized to import 20 thousand sheep and goats without customs duties (30).

With the decision taken, the General Directory of Meat and Milk Board has been the sole authority for beef cattle, and the General Directorate of agricultural enterprises has been the sole authority for breeding animal imports. The import policy adopted since 2010 has created a livestock sector based on imported animals at different scales in the country. Although the enterprises operating in the sector have the authority to import livestock, imports have lost their economic rationality due to the high tax rate they have to pay.

To ensure non-stability and break the vicious cycle in the market, but to guarantee food safety in agricultural and animal products in Turkey, elimination of structural problems, planned, the conscious and adequate transition to production, minimizing the fluctuations in production-price range, increasing producers' incomes, exports decreasing imports and "National Agriculture Project" was announced in November 2016 to increase agricultural production (31).

Within the scope of the project, necessary arrangements were made in the support provided to producers in the field of livestock and the products were included in the support areas where the most appropriate product is available and the "Local Production Support Model in Animal Husbandry" was established. Within the scope of the model, to meet the increasing demand for red meat, it is aimed to support the establishment of "Pasture Livestock Breeding Zones" in 30 provinces determined by pasture presence, cultivation culture and climate structure.

Although the realization of projects in animal production by making local and national emphasis is of great importance, the General Directory of Meat and Milk Board has been authorized to import 500 thousand non-breeding livestock with the decision of the Council of Ministers on the last day of 2016. According to the decision, the General Directory of Meat and Milk Board will import livestock and beef cattle with zero customs (32).

Due to the import applications being carried out by the official institutions, many problems occurred during the application. The genetic capacity, quality, and distribution of imported animals have been the subject of public debate. As a result of the import applications, the prices of red meat did not decrease, and the enterprises that produce livestock with domestic animals were also withdrawn from the sector, leaving production.

In March 2017, the market was intervened through the General Directory of Meat and Milk Board to prevent the rising red meat prices due to the lack of sufficient slaughterripened beef cattle in Turkey. Within the scope of the practice, fresh carcass beef was sold to butchers through the General Directory of Meat and Milk Board, and frozen carcass beef was sold to food and meat industrialists.

Although the sales prices announced for the butchers and industrialists are below the market sales prices in practice, it has been brought to the agenda that the General Directory of Meat and Milk Board creates an unfair competition environment because it is a competitor to the fattening enterprises. In February of June 2017, the upward movement in the prices of red meat continued, but it was emphasized that the increase in 
prices was mainly due to a lack of domestic supply (33).

In June 2017, the customs tax rate, which was $135 \%$ in live bovine animals, was reduced to $26 \%$, and customs tax rates ranging from $100-225 \%$ in the meat of cattle to $40 \%$ (34). With this decision, only the import authorization given to the General Directory of Meat and Milk Board in the livestock and carcass meat has been given to the entire sector. One month after the publication of this decree, a total of 975 thousand livestock import authorization was granted to the General Directory of Meat and Milk Board, including 90 thousand tons of red meat, 500 thousand cattle, and 475 thousand goats and sheep (35).

Although the imports made to eliminate the instability in red meat prices are not a solution to the price increases, there is also no fattening support paid 200 TL per animal in the "Agriculture Support Decree" announced with the decision of the council of ministers published in August 2017 (36).

With the abolition of fattening support, which was paid as 200 TL per animal, the sector's tendency to work informally has emerged with the absence of support by coming to the agenda where feeders cut the prepaid animals.

In this period, the increases in red meat prices made it obligatory for the government to intervene on this issue. While the import is the main component of the activities carried out in this regard, keeping the retail prices under control through the national market chains is the second leg of the activities carried out (37).

The General Directory of Meat and Milk Board intervened in the market and chop meat and veal cubes in the departments that it rented from conventional market chains across the country. It is planned to sell the beef minced meat packaged as a contract in private sector companies for 24 TL and beef cubed meat for 27 TL (38).

The sale of cheap meat in chain grocery stores through the General Directory of Meat and Milk Board to lower red meat prices has caused many controversies. Butchers and breeders stated that they were victims due to the sale of cheap meat. They stated that the breeders could not have their animals slaughtered due to the sale of cheap meat or had their prices cut below the production cost. On the other hand, it has come to the agenda that farms are empty in many fattening enterprises established with the credit and support provided by the state, where the breeders stopped production (39).

By working as the intervention agency of the General Directory of Meat and Milk Board, it should be distracted from an understanding of a regulatory duty based on the importonly market (40). Meat imported more than need expects to be sold at a loss in the warehouses of the General Directory of Meat and Milk Board and upset the market balances (41).

Since breeding imports have no criteria based on race, the criteria regarding the butchery fattening imports in terms of months and seasons cause many administrative and technical problems in the importing enterprises. Along with these imported animals, some animal diseases that are not seen in our country have started to be seen (41).

Lack of production planning, high input costs, gradually decreasing livestock, imbalance in raw material supply are seen as threatening livestock (42). Therefore, imports should not be made to meet the need for meat in Turkey (43).

\subsection{THE NUMBER OF LIVE ANIMALS AND THE NUMBER OF RED MEAT IMPORTS IN TURKEY DURING 2010-2018}

Although this process that started in 2010 continues until today, the amount of imports made in red meat between 2010 2018 is presented in Table-1(44).

Table 1. Number of livestock-slaughter cattle and the number of carcass and piece meat imports in Turkey during 2010-2018 Tablo 1. Türkiye'de 2010-2018 y1lları arasında yapılan kasaplık büyükbaş hayvan, karkas parça et ithalatı

\begin{tabular}{lrr}
\hline Years & $\begin{array}{c}\text { Livestock-Slaughter } \\
\text { Cattle (head) }\end{array}$ & $\begin{array}{r}\text { Carcass and Piece Meat } \\
\text { (ton) }\end{array}$ \\
\hline 2010 & 120.021 & 50.658 \\
2011 & 392.231 & 110.731 \\
2012 & 422.869 & 26.436 \\
2013 & 159.766 & 6.141 \\
2014 & 24.396 & 640 \\
2015 & 154.194 & 17.574 \\
2016 & 430.180 & 5.659 \\
2017 & 775.741 & 18.857 \\
2018 & 1.344 .563 & 55.752 \\
\hline Total & 3.823 .961 & 292.448 \\
\hline
\end{tabular}

As shown in Table-1, a total of 3,823,961 head cattle and 292,448 tons of carcasses and pieces of meat were imported in Turkey between 2010-2018.

\subsection{PROBLEMS THAT CAUSE AN INCREASE IN RED MEAT PRICES AND DO NOT CHANGE}

The most important reason for the increase in red meat prices is high production costs. The most crucial input that constitutes the production cost is feed costs. Animal feed costs are quite high compared to other countries because the current production of feed crops in the country cannot meet the needs $(15,16,17)$ the importation of a significant part of the feed raw materials used in livestock and the lack of pasturebased breeding. The high costs and increases in the exchange rate increase the prices of animal products.

In addition to the foreign dependency in the fattening material in enterprises, it increases the production costs in fattening with low capacity. The presence of a large number of scattered small-scale enterprises in the sector and the fact that 
there are many intermediaries in the market causes an increase in retail prices.

Variability, import decisions, market interventions and instability in policies implemented to lower red meat prices cause small and medium-sized enterprises to withdraw from the production.

\section{RESULT}

In the period between 2010-2019 examined in red meat; Due to the inability of the supply to meet the demand and the increase in prices, the import decisions, which are renewed every year, were taken to solve the problem. On the other hand, consumers' demand for beef meat, their purchasing decision and population are increasing every year. Interventions made to the market due to the policies implemented consist of short-term solutions to meet the current demand. In the long term, it is a requirement to reduce the dependence on red meat imports, to prevent concrete increases in the long run, and to take concrete steps for consumers, which can prevent retail price increases. Otherwise, the import process, which continues at indefinite intervals, may move domestic producers away from production day by day. Accordingly, it should be remembered that a large part of the farmers who produce animal production, which is one of the essential components of rural development, will leave the production and increase their economic and social problems both in rural and urban areas. One of the issues to be irritated by the producer in Turkey is always the possibility of obtaining import decisions going forward. For this reason, producers have reservations about starting production. To eliminate these reservations, the ministry should not take an import decision unless necessary and make the required measures to prevent the domestic producer from being damaged.

In the coming years, it may continue as a vicious circle as the red meat deficit cannot be closed and the necessity to import again. To solve the import problem; to completely stop the import, to provide incentives to increase the production amount in the country with the resources allocated to the import, to support the producers in a way that can decrease the input costs, to promote the contracted feed production for the ministry to provide cheap feed and concentrated feed for the producers, to re-establish the customized feed factories in the past, General Directory of Meat and Milk Board should quickly move away from a regulatory understanding of the market by importing meat and livestock. The General Directory of Meat and Milk Board needs to make intervention purchases as a competent intervention institution to balance the supply/demand in the market.

Considering the costs of the producers, it is necessary to determine the floor price by the General Directory of Meat and Milk Board during the slaughtering periods, to purchase from the producers with the determined base price when necessary, and thus to realize the state intervention in the periods when the prices are rising in the market, and to realize it without losing time.
Turkey meat supply, which leads to illegal slaughter outside the slaughterhouse and made cuts due to the inability to follow the correct and precise data errors in future plans and programs, is not reached. Therefore, the problem of illegal slaughtering should be resolved sustainably. Turkey should be connected directly to the slaughterhouse, and the number of ministries across the region should be updated according to the current situation.

Attain a sustainable structure without red meat, sheep and goat meat production in Turkey is very difficult. For this reason, there is a need to increase the number of sheep and goats and to expand their livestock and to encourage animal husbandry for meat production.

It should be remembered that one of the most important problems in the background of the crisis in meat is the problems caused by dairy cattle. In order to increase the raw milk prices of the Ministry to a level that will enable sustainable production, it should solve the production costs in dairy cattle production and structural problems at the point of organization and marketing.

With these solutions, it is thought that in the coming years, consumers will contribute significantly to closing the supply gap in red meat by directing their red meat consumption preferences to small animals meat. On the other hand, in order to increase the carcass yield in cattle husbandry, the use of breeds with higher meat yield in production is important for increasing the supply.

\section{REFERENCES}

1. Eştürk Ö. Albayrak N. Investigation of the Relationship Between Agricultural Products Food Price Increases and Inflation. ÜIIIID-IJEAS. 2018; 18(EYİ Özel Say1), 147-158.

2. HAYGEM. Hayvancılık Genel Müdürlüğü Hayvancılık Verileri Şubat 2018. Erişim: https://www.tarim.gov.tr/sgb/ Belgeler/SagMenuVeriler/HAYGEM.pdf. Erişim Tarihi: 09.03.2018.

3. Özertan G. Saghaian SH. Tekgüç H. Dynamics of price transmission and market power in the Turkish beef sector. İktisat İsletme ve Finans. 2015; 30(349), 53-76.

4. Çiçek H. Doğan İ. Developments in Live Cattle and Beef Import and the Analysis of Producer Prices with Trend Models in Turkey. Kocatepe Vet J. 2017; 11(1), 1-10.

5. Resmi Gazete. Et ve Balık Kurumu genel müdürlügünce kullanılmak üzere damızlık olmayan canlı sığır ve sığır eti ithalatında tarife kontenjanı uygulanması hakkında karar. Resmi Gazete Tarihi: 30.04.2010, Say1: 27567.

6. Aydin E. Can MF. Aral Y. Cevger Y. Sakarya E. The Effects of Livestock and Red Meat Import Decisions on the Cattle Fatteners in Turkey. Vet Hekim Der Derg. 2010; 81(2), 51-57. 
7. Ünlüsoy K. İnce E. Güler F. Türkiye'de kırmızı et sektörü ve rekabet politikas1. Rekabet Kurumu Yayınlar1, 3.Daire Başkanlığı, Ankara, 2010.

8. Resmi Gazete. İthalat rejimi kararına ek karar. Resmi Gazete Tarihi: 19.03.2011, Say1: 27879.

9. Resmi Gazete. İthalat rejimi kararına ek karar. Resmi Gazete Tarihi: 14.05.2011, Say1: 27934.

10. Resmi Gazete. İthalat rejimi kararına ek karar. Resmi Gazete Tarihi: 02.07.2011, Say1: 27982.

11. Resmi Gazete. Et ve Balık Kurumu Genel Müdürlügünnce kullanılmak üzere damılık olmayan canlı sığır ithalatında tarife kontenjanı uygulanması hakkında kararda değişiklik yapılmasina dair karar. Resmi Gazete Tarihi: 28.12.2011, Say1: 28156.

12. Resmi Gazete. İthalat rejimi kararına ek karar. Resmi Gazete Tarihi: 30.10.2012, Say1: 28452.

13. GTHB. Gıda Tarım ve Hayvancılık Bakanlığı, Stratejik Plan 2013-2017, Ankara, 2013.

14. Resmi Gazete. Et ve Balık Kurumu Genel Müdürlüğünün Et ve Süt Kurumu Genel Müdürlüğü adıyla yeniden teşkilatlandırılmasına ilişkin ekli karar. Resmi Gazete Tarihi: 27.04.2013, Say1: 28630.

15. Barker-Neef JM. Buskirk DD. Black JR. Doumit ME. Rust SR. Biological and economic performance of early-weaned Angus steers. J Anim Sci. 2001; 79(11), 2762-2769.

16. Umar, A. S. S., Alamu, J. F., Adenjini, O. B. Economic analysis of small scale cow fattening enterprise in Bama local government area of Borno State, Nigeria. Production Agriculture and Technology. 2008; 4(1), 1-10.

17. Arıkan MS. Gökhan EE. The effect of preliminary body weight of the Limousin cattle on the economic fattening performance. Eurasian J Vet Sci. 2018; 34(4), 233-241.

18. Kalkınma Bakanlığı. Onuncu Kalkınma Planı, Hayvancılık Özel İhtisas Komisyon Raporu, Ankara, 2013.

19. Resmi Gazete. Et ve Süt Kurumu Genel Müdürlügünce kullanılmak üzere sığır eti ithalatında tarife kontenjanı uygulanması hakkında karar. Resmi Gazete Tarihi: 23.07.2014, Say1: 29069.

20. Y1ldirım AE. "Et ithalatıyla Bosna'ya insani yardım yap1labilir mi?”. Dünya, 24.07.2014. Erişim: https:/ /www.dunya. com/kose-yazisi/et-ithalatiyla-bosnaya-insani-yardim-yapilabilir-mi/20866. Erişim Tarihi: 22.03.2020.

21. GTHB. Gıda Tarım ve Hayvancılık Bakanlığı, Besilik sığır ithali. Erişim: https://www.tarim.gov.tr/Duyuru/174/Besilik-Sigir-Ithali. Erişim Tarihi: 07.03.2018
22. Numanoğlu N. Eynehan ME. Sabuncu TB. Gıda, tarım ve hayvancılık rekabet gücü temel bulgular, TÜSİAD, İstanbul, 2014.

23. TOBB. Türkiye Odalar ve Borsalar Birliği, VII. Türkiye sektörel ekonomik şurası raporu, Ankara, 2014.

24. TCMB. Türkiye Cumhuriyeti Merkez Bankas1, Temmuz ay1 gelişmeleri raporu, 04.08.2015.

25. Resmi Gazete. Avrupa Birliği menşeli bazı tarım ürünleri ithalatında tarife kontenjanı uygulanması hakkında kararda değişiklik yapılmasına dair karar. Resmi Gazete Tarihi: 14.08.2015, Say1: 29445.

26. Resmi Gazete. Et ve Süt Kurumu Genel Müdürlügünce kullanılmak üzere sığır eti ithalatında tarife kontenjanı uygulanması hakk1nda karar. Resmi Gazete Tarihi: 28.08.2015, Say1: 29459 (1. Mükerrer).

27. GTHB. Gıda Tarım ve Hayvancılık Bakanlığ1, Kırmızı et stratejisi, Ankara, 2015.

28. Resmi Gazete. Bazı mallara uygulanacak katma değer vergisi oranlarının, özel tüketim vergisi oran ve tutarlarının ve tütün fonu tutarlarınin belirlenmesi hakkında karar. Resmi Gazete Tarihi: 01.01.2016, Say1: 29580.

29. Yıldırım AE. "Yemde KDV indirimi çiftçiye zam olarak yansıd1". Dünya, 21.01.2016. Erişim: https://www.dunya.com/kose-yazisi/yemde-kdv-indirimi-ciftciye-zam-olarak-yansidi/26862. Erişim Tarihi: 27.01.2018.

30. Resmi Gazete. Tarım İşletmeleri Genel Müdürlüğü ile Et ve Süt Kurumu Genel Müdürlügünnce kullanılmak üzere canlı hayvan ithalatında tarife kontenjanı uygulanması hakkında karar. Resmi Gazete Tarihi: 03.05.2016, Say1: 29701.

31. GTHB. Gıda Tarım ve Hayvancılık Bakanlığ1 2017 yılı bütçe sunumu, Ankara, 2016.

32. Resmi Gazete. Et ve Süt Kurumu Genel Müdürlügüunce kullanılmak üzere canlı hayvan ithalatında tarife kontenjanı uygulanması hakkında karar. Resmi Gazete Tarihi: 31.12.2016, Say1: 29935 (2. Mükerrer).

33. TCMB. Türkiye Cumhuriyeti Merkez Bankası, G1da fiyatlarında son dönem gelişmeleri, 3. Enflasyon raporu, 2017.

34. Resmi Gazete. İthalat rejimi kararına ek karar. Resmi Gazete Tarihi: 27.06.2017, Say1: 30107.

35. Resmi Gazete. Canlı hayvan ve et ithalatında tarife kontenjanı uygulanması hakkında karar. Resmi Gazete Tarihi: 29.07.2017, Say1: 30138.

36. Resmi Gazete. 2017 y1lında yapılacak tarımsal desteklemelere ilişkin karar. Resmi Gazete Tarihi: 18.08.2017, Sayı: 30158 (1. Mükerrer). 
37. UKON. Ulusal Kırmızı Et Konsayi, Kırmızı Et Sektörü 2018 Y1lı Değerlendirme Raporu. Erişim: http://www.ukon. org.tr/pdf.aspx. Erişim Tarihi: 16.04.2020

38. Dünya. Marketlerde "ucuz et" satışı başlıyor. Erişim: https://www.dunya.com/ekonomi/marketlere-ucuz-et-satisi-basliyor-haberi-388814. Erişim Tarihi: 16.01.2018.

39. Y1ldırım AE. "Ucuz etin faturası ağır olacak". Dünya, 09.11.2017. Erişim: https://www.dunya.com/kose-yazisi/ucuz-etin-faturasi-agir-olacak/390048. Erişim Tarihi: 06.02.2018.

40. GTHB. Gıda Tarım ve Hayvancılık Bakanlı̆̆1, Büyükbaş ve Küçükbaş Hayvancılık Çalıştay Sonuç Raporu. 09-11 Ocak 2018 Antalya, Türkiye.

41. TDSYMB. Türkiye Damızlık Sı̆̆ır Yetiştiricileri Merkez Birliği, Hayvancılığın yeniden inşası. Erişim: http:// online.pubhtml5.com/ebtr/kvlj/. Erişim Tarihi: 10.03.2020

42. ESK. Et ve Süt Kurumu, 2019-20203 Stratejik Plan. Erişim: https://www.esk.gov.tr/upload/Node/12352/files/ Et_ve_Sut_Kurumu_2019-2023_Stratejik_Plani.pdf. Erişim Tarihi: 22.02.2020

43. TOB. Tarım ve Orman Bakanlığ1, III. Tarım Şurası Hayvan Sağllğı ve Hayvansal Üretim Grubu Raporu, 2019.

44. ESK. Et ve Süt Kurumu, 2018 y1lı Sektörel Değerlendirme Raporu, Ankara, 2018. Erişim: https://www.esk.gov.tr/upload/Node/10255/files/2018_Yili_Sektor_Degerlendirme_Raporu-.pdf. Erişim Tarihi: 12.02.2020 